\title{
Between Reality and Symbol: Fierce Dogs and Ferocious Wolves in the DECAMERON
}

\section{Julia M. Cozzarelli}

Abstract: Non-human animals have a long history of being utilized to understand human nature, and both wild and domestic canines have been particularly intertwined with humanity since ancient times. This article examines the representation of animals, and specifically of dogs and wolves, in Boccaccio's Decameron. The analysis posits Boccaccio's canine portrayals as multifaceted in nature, serving as tools for the interpretation of human behavior and also reflective of shifting views on the purpose of animal portrayals in literature. The article explores these ideas, in part, through interpretation of Boccaccio's canines in comparison to those in other sources, with an emphasis on Dante's Divine Comedy. Given the fact that the Commedia hosts a proliferation of allegorical beasts whereas the Decameron focuses on portrayals of commonplace, living animals, one might expect significant differences in the texts' treatment of dogs and wolves. Yet, although differences exist, a study of both texts reveals a common outlook on the canine family; and the Decameron's treatment of dogs and wolves not only reflects that of the Commedia, but also the confluence of wolves and dogs with one another. The article's primary subjects of discussion from the Decameron are the widely-read story of Nastagio degli Onesti's otherworldly vision in V.8, and the lesserknown novella IX.7, featuring Talano d'Imole, his wife Margherita, and a brutal wolf attack. In addition to examining literary sources, the article touches upon hierarchical views of wild and domestic canines in daily life from the period for its analysis.

Boccaccio's seminal work, the Decameron, has long been recognized as one of the major hallmarks of transition from the medieval world to the age of humanism and the dawning of the Italian Renaissance. The representation of animals in its novelle reflects this shift, while also offering insight into the interpretation of 
the text itself. Animals were a fundamental component of Florentine life in the fourteenth century, both as practical resources and as figures populating bestiaries, fables, and legends, and their symbolic images abound in artwork from the period. The epitome of animal representation in medieval literature surely is found in the allegorical world of Dante's Commedia, which was inhabited by fantastic and terrifying beasts that were often hybrid monsters with mythological roots. In the Decameron, however, animals are not numerous, and those that do appear are typically the beasts that served as tools essential to daily life. As a result, it may be tempting to view Boccaccio's animals solely as manifestations of a more realistic approach to the portrayal of living things, moving away from their theological and allegorical roots.

But this would be a mistake. Rather, the representation of animals in Boccaccio's work reflects a merger between a naturalistic approach and the symbolic tradition. This study explores the representation of animals in Boccaccio's work and the significance of the contrast between his representations and those of Dante, with a focus on the two authors' portrayals of dogs and wolves. ${ }^{1}$ Nonhuman animals have a long history of being utilized to understand human nature, and both wild and domestic canines have been particularly intertwined with humanity since ancient times.

In the Commedia, canids often play a prominent role, with the relentless and famished she-wolf of Inferno I taking centre stage. This beast is commonly seen as the representation of the sins of incontinence, and it is she who torments the pilgrim most in the dark wood. The she-wolf is a creature with a tremendous literary heritage in Italy, not the least aspect of which is her status as the symbol of Rome and her role as the suckler of Romulus and Remus in Rome's dominant foundational myth. As Cristina Mazzoni notes, the myth of the she-wolf raises questions about the "relationship between nature and culture," with the image of the wolf nursing human boys closing the gap between the two species. As a result of this closeness, "visual and textual, physical and imaginative ways must be found [...] to reestablish difference in order to assert our humanity" (7). Humananimal similes and metaphors serve to differentiate between self and other, and the she-wolf, already innately ambiguous as a symbol, epitomizes this process

\footnotetext{
${ }^{1}$ The author is deeply appreciative of her readers' constructive feedback in the writing of this article. See also Cozzarelli, "Canines," for a different, more pedagogical approach to this topic, in which a condensed version of this discussion is used to exemplify teaching Boccaccio's works to undergraduate students through the aid of the visual arts.
} 
of distancing by association. Over the centuries, she has been, and continues to be, closely tied to misogynistic representations of female desire, echoed by the long-standing connotation of the term lupa as a female prostitute (Mazzoni 1). ${ }^{2}$ Boethius also linked humans with canines through metaphor and simile, placing wolves, hounds, and foxes in an ethical context as emblematic of humans falling into vice. ${ }^{3}$

The wolf's inclusion in the Commedia is consistent with Mazzoni's interpretation as well as the era's widespread notion of the wolf as an icon of rapacity (Rowland 162). The first canto of the Inferno reflects the conception of the animal as ravenous and insatiable, qualities intimately tied to the sin she represents, introducing her as "una lupa, che di tutte brame / sembiava carca ne la sua magrezza" ("a she-wolf, that in her leanness seemed laden with every craving"; Inf. I.49-50). ${ }^{4}$ Dante's Virgil echoes this language, saying, "questa bestia [...] ha natura sì malvagia e ria, / che mai non empie la bramosa voglia, / e dopo 'l pasto ha più fame che pria" ("this beast $[\ldots]$ has a nature so vicious and malign that she never sates her greedy appetite and after feeding is hungrier than before"; Inf. I.94-99). The pilgrim curses the she-wolf and her insatiable hunger again in Purgatorio XX, on the terrace punishing avarice (9). The wolf herself is present neither there nor elsewhere in the Commedia besides the introductory canto, underscoring the animal's value as a symbolic image rather than a living one.

The masculine variant of the term lupa has a similar purpose in Inferno VII, again in the context of avarice, where Virgil commands the raging, babbling Plutus, the circle's guardian and human/demon hybrid, "Taci, maladetto lupo!" "Silence, accursed wolf?"; Inf. VII.8). Indeed, the wolf in its masculine form is reduced to a figurative signifier alone. In Purgatorio XIV, lupi represent the debauched people living along the Arno in an allegorical description of the river's squalid and evil surroundings, replete with several types of reprehensible animals ("brutti porci" ["filthy hogs"], squabbling dogs, evil wolves, and deceitful foxes; 43-54). The only "positive" use of the term in the entire Commedia — and even then it is positive only

\footnotetext{
${ }^{2}$ See also Rowland 164.

${ }^{3}$ In Book IV of the Consolation of Philosophy, Boethius emphasizes the "loss" of human nature through sin by explaining that greedy, violent thieves are said to be wolves; a "fierce man [...] working his restless tongue at lawsuits" is called a hound; and men who lie in ambush are often compared to foxes (82).

${ }^{4}$ Texts and translations for the Commedia are from the Charles S. Singleton six-volume edition.
} 
from the viewpoint of the person using it-is when the damned Ugolino, infamous for his ravenous gnawing on the brains of his enemy in Hell, employs it as a metaphor for himself and for his children when he recounts an ominous prophetic dream (Inf. XXXIII.29). Although most readers, including Beryl Rowland (163), see this allusion to wolves as sympathetic due to the narrative's tragic context, I would argue that the poet uses the wolf metaphor here to underscore the flawed character of the speaker, especially in light of the fact that wolves are portrayed in strictly negative terms throughout the rest of the Commedia. Once again, the wolves are not true characters here: they serve as symbols alone. ${ }^{5}$

Boccaccio must have been aware of the wolf as a symbol of avarice and rapacity, and we know this was certainly the case by the time he wrote his expositions of the Commedia. In his allegorical exposition of Inferno I, Boccaccio describes the transformative nature of sin, through which sinners lose their humanity by allowing their carnal desires to subsume their reason. He does so with examples using non-human animals, including the assertion that "il rapace diventa lupo, perché il lupo è rapacissimo animale" "the rapacious man becomes a wolf because the wolf is a rapacious animal"). ${ }^{6}$ Later, in describing the she-wolf's presence in the dark wood, Boccaccio renders her at length in an emphatically harsh manner. She is a "fiero animale e orribile" ("ferocious and horrible animal"), "famelico e bramoso" ("ravenous and greedy"), and cowardly, mating with only the most wretched of males, in the same way that avaricious and greedy people hang on to their money (I.II.125-133; 100-101). Boccaccio repeatedly uses these, and similar, adjectives and motifs throughout his description. Moreover, he explains, the she-wolf not only represents these sins but is also equated with the devil, as a "rapacissimo ed insaziabile divoratore" ("exceedingly rapacious and insatiable devourer") who threatens human beings with ruin (I.II.141; 103).

${ }^{5}$ Other wolf references in the Commedia include examples of papal corruption using the metaphor of wolves disguised as shepherds (Par. XXVII.55-56); a simile representing the pilgrim torn between conflicting doubts, like a lamb between two wolves (Par. IV.6); and a comparison likening exile to a lamb barred from its former haunts by enemy wolves (Par. XXV.6). Rowland describes Dante's use of the wolf to refer to clergy and contemporaries as consistent with its use as "a symbol to denounce any person who misused his power, whether religious or secular” (163).

${ }^{6}$ Italian text is from Esposizioni (I.II.73); translation is from Boccaccio's Expositions (91). Boccaccio also explains the appellation of Pluto as a wolf in Inferno VII as logical, given that the sin punished in that circle is avarice (VII.I.13; 333). 
The role of wolves in the Commedia, and as seen in Boccaccio's expositions, is consistent with theological and philosophical explorations of the time, when studies on animals were intended to teach us about humanity rather than animals themselves, and animal behaviour was interpreted symbolically in the moral exemplars of the influential Physiologus and, later, the bestiaries that derived from it (Resl 1). The Physiologus was an important reference for understanding animals in the medieval age, drawing from the Bible and other ancient texts, including those of Aristotle. Mythological and fantastical creatures held equal standing with the living in these works, which drew their authority from the earlier texts rather than from observation of the creatures themselves. Fables and religious exemplars embodied these ideas. As Joyce Salisbury has noted, predatory animals typically represented nobility in the works of the medieval fabulists, although the wolf was considered villainous "not because he was a predator but because he was excessively greedy," with his gluttonous, murderous nature seen as the cause of "disruption in the social order" (102). But wolves were also real, and wolves, as hunters' natural competitors, were avidly hunted and especially valued as trophies in the medieval age (Resl 6). Indeed, the hunting of wolves was not only permitted but also rewarded (Rowland 164).

Although the Decameron is dramatically different from the Commedia in style, structure, and content, the wolf appears in the Decameron, too, with its largest role in novella 7 on Day IX. ${ }^{8}$ This is one of the work's shortest novelle, featuring Talano d'Imole's dream that his wife, Margherita, who is described as a beautiful but extremely unpleasant and cantankerous person, is attacked by a wolf

\footnotetext{
${ }^{7}$ In the Bestiario toscano, for example, a fable relating the interaction between a wolf and a deer is used to equate the wolf with the devil and to urge the human faithful to drive away the devil with good deeds rather than sin. The Bestiario also contains a reference to the she-wolf's habit of selecting the most miserable of mates. See Garver and McKenzie 73-74, 89, 90. The moral exemplars were also evident in early Italian literary passages. See, for example, the legend of St. Francis and the wolf of Gubbio, where the wolf is used to represent corruption and sin, and St. Francis's taming of it indicates the ability of religion to reform the soul. See the series $A$ Cultural History of Animals (Kalof and Resl) for an overview of the role of animals in Western culture from the medieval age through modernity, with focused examinations of their function in economics, society, science, philosophy, and art.

${ }^{8}$ As living animals (rather than strictly similes or metaphors), wolves appear also in novella V.3 as a pack that devours a beloved horse. Although wolves are mentioned in novella II.9 as well, they are fictitious, part of a story invented to conceal the escape of the wife that Bernabò had ordered killed.
} 
and brutally disfigured. In his dream, Margherita is wandering in a very lovely wood near their home, and the wolf, "grande e fiero" ("large and ferocious")," suddenly leaps at her throat, tearing at her face and neck. Talano relates this dream to his wife with the warning that she should stay away from the woods, but she attributes the warning to motives far less generous than concern. Perhaps, she thinks, this is his secret desire-or even that the dream was fabricated to conceal a love tryst! Naturally, the ungrateful and suspicious wife then seeks out the woods, watching for her husband from a concealed location. She waits, "senza alcun sospetto di lupo, e ecco vicino a lei uscir d'una macchia folta un lupo grande e terribile" ("without the slightest fear of there being a wolf in the area, [when] suddenly, from a dense thicket near her, there emerged a large and ferocious wolf"; IX.7.12; 587). The wolf appears exactly as predicted and is described with adjectives nearly identical to those used in the dream, in complete contraposition to the great confidence with which Margherita had dismissed the veracity of her husband's account. ${ }^{10}$

Margherita is barely able to utter a cry for help before the wolf latches on to her throat, dragging her away "come se stata fosse un piccolo agnelletto" ("as if she were a baby lamb”; IX.7.12-13; 587). The narrator, Pampinea, emphasizes the woman's inability to scream under the grip of the wolf's jaws. Margherita's incapacity to speak is not inconsistent with a mysterious power that wolves were said to possess at the time, and which is referred to in literature dating back to the first century: ${ }^{11}$ if a wolf sees a person before it itself is seen, the person temporarily loses the ability to speak, whereas if the person sees the wolf first, the wolf loses its ferocity. In this case, however, there is also a very real, physical cause for the victim's inability to cry out, as the wolf's teeth are buried in her throat.

\footnotetext{
${ }^{9}$ Italian excerpts come from Decameron, edited by Vittore Branca (IX.7.6); translations, from The Decameron, translated by Mark Musa and Peter Bondanella (586).

${ }^{10}$ Giusti (118) discusses this tale as an example of one of five visions or dreams in the Decameron, calling attention to Panfilo's words on premonitory dreams in the introduction to IV.6, where he warns those who are wicked to believe dreams that contain ominous messages over those that seem to portend good for the dreamer. See also Marchesi for detailed discussion of Panfilo's thoughts on dream interpretation in IV.6 ("Dire").

${ }^{11}$ See Badke's Medieval Bestiary, which includes excerpts from Pliny the Elder (first century) and Bartholomaeus Anglicus (thirteenth century), for more details on this characteristic of the wolf. It is also mentioned by Albertus Magnus in the De animalibus (p. 1518).
} 
This is not Boccaccio's first reference to a wolf lunging at the throat of a human victim. In his Latin Eclogues, the young shepherd Alexis wanders into the wood at night, and there he is attacked and killed by a rabid, pregnant wolf. The line, "cuius sevissima guctur dentibus invasit" ("this savage beast sprang up and plunged her teeth into his throat"), mirrors the language of the novella, but in this case, no one can pull the wolf away, and the end result is fatal for the victim. ${ }^{12}$ This passage, composed not long before the Decameron, is commonly believed to represent Queen Joanna's suspected murder of her husband, Andrew. ${ }^{13}$ A pregnant, raging lupa evokes traditional associations with unrestrained female lust and, even more notable here, the allegory depicts a violent conflict between a wife and her husband, ending in the permanent silencing of the victim.

The wolf of medieval fable was already a "metaphor for nobility gone astray," employed to criticize the intemperate behaviour of the upper classes (Salisbury 102). As such, the wolf could also be interpreted as an agent for corrective action. Indeed, the wolf that attacks Margherita in the Decameron seems to serve this purpose, and he can be read as a representation of the husband, or as acting in his stead. The wolf plays a punitive role in this novella, functioning as a tool designed to support a frustrated but powerless husband in a realignment of what would have been considered a more proper marital hierarchy, one in which the wife should willingly submit to her husband's wishes without complaint. Pampinea criticizes Margherita for her disagreeable and confrontational way of speaking, and in the story, the wolf, at least temporarily, renders Margherita mute. Moreover, although the victim survives the attack, she has lost her sole admirable quality because her beautiful face is now "sozzissima e contrafatta" ("hideous and disfigured"; IX.7.14; 587). The tale ends with Margherita crying through the remainder of her life, vainly regretting her bad temper and her refusal to believe that her husband's dream was prophetic. Thus, the proper hierarchy has been restored: the masculine wolf (no lupa here!) has regained his power, and the wife has been transformed, through both simile and symbol, into a little lamb.

A savage wolf attack may seem an extreme measure to correct the disposition of an irate human woman, but, in the Trattatello in laude di Dante, Boccaccio states,

\footnotetext{
12 "Carmina" III.151-152; the translation is from Eclogues 26-27. In the latter version, the line is, "cuius surgens sevissima guctur / dentibus invasit" (III.86-87).

${ }^{13}$ See Eclogues 210-212 for Smarr's notes on the eclogue's date and the episode's meaning.
} 
né alcuna fiera è più né tanto crudele quanto la femina adirata, né può viver sicuro di sé, chi sé commette ad alcuna, alla quale paia con ragione esser cruciata; che pare a tutte.

(no wild beast is as cruel as or more cruel than an angry woman. No man can live in safety who trusts himself to a woman who believes she has some reason to be enraged — and all women act like that. $)^{14}$

Given such a sentiment, the two characters involved in this novella's violent encounter appear to be more evenly matched. A ferocious wild animal requires another of equal ferocity to attempt to subdue her. Margherita's punishment, like a Boccaccian contrapasso, is carefully designed to counterbalance her particular transgression. Its result, the obliteration of Margherita's beauty, is also a means of eliminating potential future conflicts. In the Trattatello, Boccaccio opines on the problem that a beautiful wife poses: with countless admirers who "infestissimamente combatter[anno] il non stabile animo" ("ceaselessly besiege her unstable mind"), "quel, che molti desiderano, malagevolmente da alcuno si difende" ("it is hard for one to defend what is desired by many"; 53; 16).

In the Decameron, the long-standing associations of wolves with predatory lust in the guise of men or lascivious women (with their victims represented as sheep) have not been forgotten either. ${ }^{15}$ Marina Scordilis Brownlee (262) has highlighted the symmetrical usage of sheep and wolves in Day III as a way for Boccaccio to undermine the sexual differentiation of the brigata's members. But, in the tale of Margherita, the symbolism of the wolf reinforces sexual difference instead.

Margherita's inversion of the proper gender hierarchy constitutes a threat to the norms of civilized society, and Boccaccio deliberately chooses an encounter with a wolf to represent this threat. Unlike most of the other animals that

\footnotetext{
14 “Trattatello," vol. 3, 54; the translation is from The Life of Dante 16.

${ }^{15}$ For example, wolves also could be seen as symbolically linked with these traits in both men and women in novella II.9. There, Zinevra must defend herself against claims of infidelity made by multiple men, including a possessive husband and a man who had attempted to seduce her. Their representation in this novella as "real" wolves that turn out to be fictitious may also be seen as the reverse of their portrayal in novella IX.7, where the symbolic wolves of dream become real. See also Rowland 164-165, for more references on the sexual symbolism of the wolf in literature.
} 
Boccaccio includes in his Decameron, the wolf is not a domestic animal, and even wolves in the wild had become scarce by this time. However, in the Middle Ages, roaming wolves were reputed to prey upon humans, and the importance of this notion lies not in its factual reality (or lack thereof) but, rather, in the fact that this was a topos "often deployed to express the collapse of civilization and the concomitant return of wilderness and chaos" (Resl 4). Margherita's challenge to order was an invitation to chaos, shaped in the form of a wolf attack.

Margherita's assault takes place in "un bosco assai bello" (IX.7.5), a wooded setting that, despite its beauty, is appropriate for the threatening chaos of the wild. This venue also functions to link the gruesome episode with another horrifying canine attack, in one of the most well known novelle of the Decameron: the eighth tale of Day V, featuring Nastagio degli Onesti. However, in Nastagio's tale, the aggressors are not wild wolves; they are domestic dogs.

Although dogs and wolves are closely related, the domesticity of the one and the wildness of the other would seem to be reason enough for literature to treat them as highly distinct. In the Middle Ages, dogs shared the home with people not only as companions but also as status symbols. Men in the wealthier classes hunted for entertainment and to display power and status, and skilled hunting dogs were of particular value. The feminine counterpart to the hunting dog was the lapdog, kept by wealthy women for diversion and companionship (Resl 5). ${ }^{16}$ The hierarchy in the canid family is also apparent in Dante's first canto, where the saviour who will eventually rout the evil lupa is represented by a veltro, a noble greyhound (Inf. I.103). This valued breed was one of three types used for hunting that Albertus Magnus described in De animalibus in the thirteenth century ${ }^{17}$ and was thought to be the breed that hated wolves most of all. ${ }^{18}$

Studies of medieval works, including those of Albertus Magnus, have shown that Europeans not only had emotional feelings for animals but they also believed that animals had feelings as well (Resl 24). Tales demonstrating the self-sacrificing loyalty of faithful dogs were widely disseminated, and dogs were

\footnotetext{
${ }^{16}$ Hunting with falcons and hunting with packs of hounds were pursuits linked with wealth and nobility; archery, hunting with one or two dogs, trapping, and other less prestigious methods were used by those hunting for food, as described in Smets and van den Abeele 61-63.

${ }^{17}$ For more on the qualities and breeding of the bloodhound, greyhound, and mastiff, see $O n$ Animals 1457-1459.

${ }^{18}$ Boccaccio himself mentions the greyhound's dislike of wolves in the Esposizioni (I.I.133).
} 
commonly represented as symbols of guardianship (Rowland 62). In addition to being praised for their wisdom, ${ }^{19}$ dogs were reputed to be capable of recognizing angels, and even Brunetto Latini remarked on the adoration of the dog for humans (Manguel 16). Indeed, as Brigitte Resl writes, the "feelings of dogs for their masters are so frequently written about in the medieval period that they can appear stereotypical" (25).

Despite these warm praises, dogs were not universally regarded in a positive light. Negative associations with dogs abound in the writings of the medieval and Renaissance periods, including references to their ties with sin, the devil, and sexual perversion (Rowland 60-61) and reinforced by consistently negative portrayals in Christian doctrine (Resl 25). ${ }^{20}$ In the metaphors of medieval fable, the high status normally attributed to predators is diminished in dogs because of their primary function as "servants" (Salisbury 104). Moreover, the character traits attributed to dogs seem more akin to those of their relatives, the wolves. In both Dante's and Boccaccio's texts, dogs and wolves are even more closely linked to one another, with connections not only through the environments in which they lurk but also in the very adjectives that describe them.

In the Inferno, dogs, like wolves, are described as voracious brutes, and the creature most emblematic of this trait is surely Cerberus, the three-headed dog that both guards and torments the gluttons. He barks as the sinners he flays howl like dogs in the dirty rain (Inf. VI.18-19). When Virgil throws dirt to distract the raging monster, his three gullets are described as bramose ("ravenous"; Inf. VI.27), the same adjective used earlier for the she-wolf, a creature also willing to devour dirt. ${ }^{21}$ Boccaccio echoes these characterizations in the Esposizioni, where

${ }^{19}$ In the notes to Diana's Hunt (186), Cassell and Kirkham note this trait, as well as the dog's reputation for moderation, in their explanation of the influence of the bestiary tradition on Boccaccio's Caccia di Diana.

${ }^{20}$ In the Bestiario toscano, for example, the dog is said to be faithful to its benefactors, but the true focus of the discussion is what is described as its repulsive habit of reingesting its own vomit. The vast majority of the entry on dogs is dedicated to explaining how repeated sinning by humans is analogous to the dog's loathsome behaviour. See Garver and McKenzie 28-30.

${ }^{21}$ Singleton observed this connection, as reflected in the veltro's aversion to eating dirt, in his commentary on Inferno. He also points out that Cerberus was the devourer of the dead in mythology (97-99). For more discussion on Dante's treatment of Cerberus, and how it diverges from classical and mythological sources, see Kleinhenz. Kleinhenz also highlights connections between Cerberus, Pluto, the lupa, and Lucifer within Dante's text (“Infernal”). 
he commends the choice of Cerberus for this canto, for "ogni cane naturalmente è guloso" ("all dogs are naturally gluttonous") as well as being great cravers (VI. II.51, 54; 328).

Again, Cerberus is an allegorical composite creature drawn from mythology. In this case, Dante has primarily modified a version of the beast found in the Aeneid, although Dante's representation of its behaviour is vividly canine. This merger of animal and human is truly monstrous, and, as Christopher Livanos writes, 'One of the meanings of the word monstrum is 'sign', so the monsters appearing near the entrance of each new section of Hell function as emblems of the sin being punished therein," so "for Dante the connection between monstrum and monstro is not an obscure etymological point but a fundamental matter" (82-83).

Monsters are symbols, and ones typically tied to evil in the Commedia, but this does not mean that "purer" uses of canine terminology are free from similar connotations. The malebranche demons in Hell have names that include Graffiacane ("Dog Scratcher") and Cagnazzo ("Wicked/Ugly Dog"), and the entire Commedia is rife with the use of the term "cane" as an insult. ${ }^{22}$ As Alberto Manguel observes, "Angry, greedy, savage, mad, cruel: these are the qualities that Dante seems to see in dogs and applies to the inhabitants of Hell" (14). Indeed, the greyhound of Inferno I is the only positive example of domestic canines in this work (Manguel 14).

Given the fact that the Commedia hosts a proliferation of allegorical beasts, whereas the Decameron focuses on portrayals of commonplace, living animals, one might expect significant differences in their treatment of dogs and wolves. Yet, a study of both texts reveals a common outlook on the canine family, and the Decameron's treatment of dogs and wolves not only reflects that of the Commedia, but also the confluence of wolves and dogs with one another. Indeed, the very same adjectives—grande ("large") and fiero ("fierce")— that were used to describe the wolf that attacked Margherita are used for the dogs in novella V.8. ${ }^{23}$ In the latter tale, the scene is set when the frustrated lover Nastagio, lost in the thought of his hopeless love, wanders into a pine forest where he witnesses the savage, otherworldly scene featuring a dog attack. Branca has noted the similarity of the lover's distraction to Dante's thoughtful state as he entered into the Earthly Paradise in

\footnotetext{
22 See also Inf. VIII.42, where Virgil, in a display of righteous wrath, refers to the condemned souls of the wrathful as cani.

${ }^{23}$ Branca underscores this commonality of terms in his notes for the Decameron (vol. 2, 1081).
} 
Purgatory (Decameron 674). But this setting is also reminiscent of another wood the pilgrim entered, unaware-one that held a she-wolf in Inferno I. Boccaccio himself links Nastagio's wood to the dark wood of the Inferno by explicitly placing them in opposition in his exposition of that canto, writing " $M i$ ritrovai, errando, per una selva oscura, a differenzia d'alcune selve, che sono dilettevoli e luminose, come è la pineta di Chiassi" ("I found myself, wandering, in a dark wood, as opposed to some other woods that are pleasant and luminous like the pine forest of Chiassi"). ${ }^{24}$ Although Boccaccio presents the two woods as antithetical, the act itself serves to associate them with one another.

In his woods, Nastagio is startled by the sight of a beautiful girl, ignuda ("naked") and graffiata ("torn"), crying for mercy. At her flanks, "due grandi e fieri mastini, li quale duramente appresso correndole spesse volte crudelmente dove la giugnevano la mordevano" ("two huge and ferocious mastiffs that every so often would catch up with her and bite her savagely"; V.8.15-16; 360). A human being hunted by dogs in the woods is not an idea original to Boccaccio. It is certainly suggestive of the myth of Actaeon, who is ripped apart by his own hunting dogs after seeing Diana nude. But Actaeon had been turned into a stag by Diana, making him a natural prey animal for his trained dogs, whereas this victim is still human.

One widely-recognized influence on Boccaccio's novella is a religious exemplum by the Dominican friar Iacopo Passavanti; it was narrated as part of a sermon in 1345 and later published in Lo specchio della vera penitenza (46-48). ${ }^{25}$ The exemplum illustrates the perils of sin through a story that shares many key similarities with Boccaccio's tale. It features a humble coal merchant's vision of a knight astride a black horse, both exhaling flames, that pursue a terrified naked woman. The vision culminates with the knight stabbing the woman and throwing her into a fire. The infernal scene must play out repeatedly until both souls have served their penance for an adulterous affair and a murder committed while they lived. This exemplum is noteworthy for its similarities to Boccaccio's tale, but one major, and significant, difference is the absence of dogs. In this, the source that may have played a larger influential role is that of Dante's spendthrifts in Inferno XIII. These poor souls, recklessly and self-destructively wasteful of their possessions in life, are

\footnotetext{
${ }^{24}$ Esposizioni I.I.6; Expositions 54 (see also note 4 on p. 610).

25 The sources for this tale are not limited to the religious exempla. See Baldi and Sinicropi for more on other sources that play a role in the novella.
} 
forever fleeing through another dark forest - the Wood of the Suicides, and they, too, are described as "nudi e graffiati" ("naked and torn"; Inf. XIII.116). They are pursued and mauled by "nere cagne, bramose e correnti" ("black bitches, eager and fleet"; Inf. XIII.125).

In Dante's text, it is clear that the reader is meant to imagine the attack on the spendthrifts as a hunting scene, even though no human hunter is present. The sounds that precede the emergence of the spendthrifts are compared to those of a wild boar hunt, and the dogs are eager, "come veltri ch'uscisser di catena" ("like greyhounds loosed from the leash"; Inf. XIII.126). Dante used similar language to vividly describe a hunt in the sonnet "Sonar bracchetti" ("Hounds baying"), a poem that emphasizes the separation between the thrill of such masculine pursuits and the world of the feminine. The sonnet opens with a dramatic series of images describing the hunt, including the verse, "di guinzagli uscir veltri correnti" ("greyhounds loosed running from leashes"; 315). ${ }^{26}$ In the second part of the sonnet, the narrator finds himself torn between thoughts of his beloved and the excitement of the hunt. But in the episode of Inferno XIII, the hunt as a motif is stripped to its bare essentials. Not only are the concerns of love set aside, but the scene also lacks any human agency; it is only the violence of the dogs that we witness.

Boccaccio, however, does include a huntsman in his episode, and one who plays a critical role in the scene. When the knight arrives on a black horse, "forte nel viso crucciato" ("his face flushed with anger"), he yells at Nastagio to leave him be, and to allow him and the dogs to punish "questa malvagia femina" ("this wicked woman") as she deserves (V.8.16, 19; 360). His "lascia fare a' cani e a me" ("leave it to me and these dogs") is an apt choice of words, for here human and beast are joined not only semantically, but also through the traditional associations of dogs with wrath. The knight stops speaking, and "a guisa d'un cane rabbioso" ("like a mad dog") he cuts his victim open with his sword and feeds her entrails to his dogs, who immediately devour them with ravenous hunger (V.8.29; 361). In the Inferno, the dogs themselves dismembered their victims; here, the dogs require the intermediary of their doggish master before they can feast.

Cormac Ó Cuilleanáin wrote that the Decameron's beasts have a "restricted mimetic range," their author being neither a scholastic writer, nor a proponent of the ideas set forth in the bestiaries, nor even a close observer of animal life. Rather, he said that Boccaccio uses "a variety of animal images to match the variety of

\footnotetext{
${ }^{26}$ Translations from "Sonar bracchetti” are mine.
} 
human nature, or to illustrate the progression of human adventure" (87). The treatment of the canids in the Decameron does not seem inconsistent with this observation, and, certainly, the hunt is an appropriate choice for inclusion here, as it was a real-life adventure that Boccaccio knew well or even practised himself. ${ }^{27}$ Nevertheless, a study of Boccaccio's early works, and the Caccia di Diana in particular, demonstrates that Boccaccio was also well aware, and able to avail himself, of the traditional symbolic and moral associations of animals set forth in the bestiaries and in Biblical exegesis. ${ }^{28}$ However, the animals of the Decameron go beyond such representations in order to serve a more complex, expository purpose in their tales, even as their roles are supported by their traditional associations.

The inclusion of a hunt in novella V.8 is an inversion of earlier fictions, including Boccaccio's own, that used hunting as a metaphor for amorous pursuits, as the hunting term "venery" itself implies. As was the case with the canine animals used in hunting, views on the sport demonstrated conflicting attitudes at the time. The most critical view was that of the Church, which officially condemned hunting as a worldly and vain pursuit. Despite this stance, hunting was an extremely popular and widespread activity, even among the clergy, with Albertus Magnus as a prominent example (Smets and van den Abeele 73-74). ${ }^{29}$ In the Decameron, Boccaccio draws on all of these perspectives. The dogs in the novella of Nastagio, like the wolf that attacked Margherita, serve once more to highlight sexual difference and to enforce the resolution of sexual conflicts. In Dante's punishment of the male spendthrifts, the dogs in pursuit had been cagne ("bitches"), bearing the same feminine gendered label as the dogs that had hunted the wolves in Ugolino's allegorical dream. ${ }^{30}$ But in Boccaccio's text, the wolf was a masculine lupo, and here in the novella of Nastagio, the dogs are also referred to in the masculine form, sometimes as mastini ("mastiffs") and at other times as cani ("dogs"). Despite the

\footnotetext{
${ }^{27}$ For more on this, see the introduction to Diana's Hunt-Caccia di Diana (Cassell and Kirkham 19).

28 Cassell and Kirkham observe that, although "exactly which texts Boccaccio may have consulted has not been established [...] the bestiaries generally retain certain unchanging features, and these are reflected in Diana's Hunt, very much a product of the most traditional, enduring lore" (14).

${ }^{29}$ See also Cassell and Kirkham 19 for more details on these positions.

${ }^{30}$ In the dream, lean female hounds ("cagne magre"; Inf. XXXIII.31) are set upon a male wolf and his male offspring ("lupo e lupicini”; Inf. XXXIII.29).
} 
influence of his source, Boccaccio has chosen to have his female victim hunted by male dogs.

The contrast between the hunted and her human hunter-a dynamic entirely absent from Dante's Inferno XIII—is stark in Boccaccio's tale. The hunted woman is presented simply as a giovane ("young woman"), whereas her pursuer is introduced with the term cavalier ("knight"; V.8.15, 16). ${ }^{31}$ She is naked and on foot; he is armoured and astride a charger, itself a symbol of high status, and aided by his savage dogs. His appearance and his possessions denote nobility and, also, due to the sport in which he is engaging, masculinity, whereas the nudity of the fleeing victim displays her vulnerability and eradicates any markers of status whatsoever. Even the knight's act of feeding her heart and organs to the dogs underscores her lowly status. In the Middle Ages and Renaissance, it was common for hunters to reward their dogs by feeding them the entrails of their catch as part of the ceremonial rituals of the hunt (Smets and van den Abeele 61). ${ }^{32}$ By doing this here, the knight is demonstrating the worth of his dogs in reverse proportion to the worth of his human victim. This dichotomy is further reinforced by the dogs themselves: they are referred to here as mastini ("mastiffs"; V.8.16; 360), and this choice of terminology is significant. Although mastiffs were sometimes used in the hunt, at the time, they were considered more useful for guard duty, and they were not as valued as other types of dogs in the sport (Smets and van den Abeele 61). Presumably, this particular quarry does not merit the deployment of even the best weapons in the hunter's arsenal. In effect, the woman's treatment undoes the inversion of social status that was evident in the earthly love stories of both Nastagio and the Knight. In life, the rejection of these men by disdainful females undermines the rank of the men in pursuit and imperils their wealth.

The power that the masculine sport of hunting ${ }^{33}$ denoted in the upper classes is one mirror of the relationships of power between the genders in this tale. Dante

\footnotetext{
${ }^{31}$ My translation.

32 In a similar vein, a huntress in the Caccia di Diana feeds her eagle the heart of a leopardess that he has just killed for her ("Caccia" III.31-33). Salisbury remarks that this ritual, the curée, forged a bond between participants in the hunt as a form of celebration (38).

${ }^{33}$ Although women sometimes participated in mixed hunting parties, they were much more likely to participate in falconry rather than hunt with hounds (Smets and van den Abeele 59). The author's preface to the Decameron also firmly situates hunting within the realm of masculine pursuits, unavailable to women suffering from the pangs of love and boredom (Decameron, "Proemio" 12).
} 
used the hunt to highlight masculine distractions and the draw of the feminine world in "Sonar bracchetti" (a theme echoed in the Decameron's "Proemio"), but, in novella V.8, Boccaccio places the genders in opposition to very different effect. Once again, we have female characters who are unable to speak fully; one, the ghostly victim of the endless attack, and the other, a living woman who speaks, indirectly, only to offer herself to Nastagio after her coercion through fear. Ray Fleming has described this silencing in Day $\mathrm{V}$ as a rendering of women into nameless objects of trade within a world of male power and dominance (35-36). Here, too, the wilderness of the woods serves as the venue for a lesson aimed to support this structure-and the women are the ones to whom this lesson is directed.

In Dante's Inferno XIII, the woods are made of suicidal souls, and those condemned to eternal canine dismemberment are destructive squanderers of wealth. In Boccaccio's tale, the condemned knight was also a suicide. Nastagio, likewise, is a protagonist introduced as one who, in his fruitless pursuit of love, had considered suicide and, due to his continued lavish spending, "sé e 'l suo avere parimente fosse per consumare" ("was on the brink of wasting away both himself and his fortune"; V.8.9; 359)..$^{34}$ In his expositions of the Inferno, Boccaccio claimed that the spendthrifts were torn apart by dogs in proportion to the number of afflictions they endured in poverty, and their consciences were torn "da amarissime rimorsioni" ("by exceedingly bitter remorse”; XIII.II.16; 530). Manguel has noted also that there "was a superstition in Florence that to dream of a dog, especially of a dog nipping at your heels, was a herald of sickness and even death" (17). Nonetheless, Nastagio, the spendthrift and potential suicide witnessing a violent, infernal vision involving hunting dogs, does not interpret these ominous signs as a message for him, nor does he undergo a crisis of conscience. Instead, after a brief wave of fear and compassion (requiring only one line in the text), he decides that the scene "dovergli molto poter valere" ("[might be very] useful to him"; V.8.32; 361). ${ }^{35}$ Nastagio's staged showing of the infernal scene to his love object teaches a lesson not only to her but also to all the women of Ravenna who, from then on, are said to have been much more amenable to their men's desires.

The tale ends happily for Nastagio when his beloved consents to marry him, satisfying the directives of the day's theme. The permanence of this "happy"

\footnotetext{
${ }^{34}$ Houston has noted that Nastagio's link to the spendthrifts makes him not only "a spectator, but a participant in this drama" (166).

${ }^{35}$ Note that I have modified the translation here.
} 
outcome for either partner is questionable, however. The tale's ending undercuts the value of marriage as favourable to all parties, and this particular marriage may even ultimately be barren, as Marchesi's study of the dynastic connections in the narratives of Filostrato, Filomena, and Dante has shown ("Intenzionalità," 39-41). This pessimistic prognosis is consistent with Boccaccio's low esteem for marriage expressed in other works as well, such as the Trattatello. ${ }^{36}$ Moreover, by the end of the tale, the lesson that Nastagio's experience has taught him is not one that reflects either his own failings or the complex nature of romantic desire. Instead, Nastagio simply learns how to utilize the infernal message to force his will on to another person.

In this sense, Boccaccio's treatment of Nastagio's adventure is consistent with what Robert Hollander has noted regarding the relationship between Boccaccio's work and that of his influential predecessor. If the Decameron can be viewed, as Hollander asserts, as a "corrective" commentary on the Divina commedia, then Boccaccio seems to be highlighting humankind's inability to function in accord with traditional morality, as well as the futility of changing human behaviour; yet, "he wants to enable us to think more clearly about our human nature" (Hollander 17, 85, 92). Jason Houston, in a similar vein, describes the irony of this tale as both a Dantean moment and "a critique of Dante's system of divine justice that takes root in vengeance and violence" (168). ${ }^{37}$

Boccaccio's treatment of his animal characters reflects his relationship with Dante's work while also, ultimately, being a parodic critique of it. Houston, in describing Boccaccio's development as a Dantista, refers to Boccaccio as an imitator of Dante in his earlier works, including the Caccia di Diana, a text constructed around a plethora of animals, one of which is the narrator himself $(163) \cdot{ }^{38} \mathrm{In}$ the Caccia, the animals serve a function similar to the one they served in the Commedia; they are strictly symbolic, each beast representative of an evil or sin

\footnotetext{
${ }^{36}$ After decrying the negative consequences of marriage, especially on great thinkers such as Dante, Boccaccio claims that he is not suggesting that no one marry. Rather, he says, philosophers should leave marriage "a' ricchi stolti, a' signori e a' lavoratori" ("to wealthy fools, to noblemen and peasants"; “Trattatello," 59; The Life of Dante 17).

${ }^{37}$ Here, Houston reads the tale as an ironic portrayal of Nastagio's "path to redemption" through a wealthy marriage and a return to the "civil tranquility" of Ravenna.

38 One example of imitation in the Caccia di Diana includes Boccaccio's nod to Dante's malebranche devils when, at the only time the dogs are called by name, those names include Graffiacani and Dragone ("Caccia," XIV.5-6).
} 
that the ladies of the hunt conquer and then transform through their virtues. ${ }^{39}$ The hunted beasts serve as a means for Boccaccio to exalt the women who were able to, metaphorically, conquer vice through the ennobling power of their beauty and love. The text is an allegory rich with bestiary symbolism, and it demonstrates the breadth of Boccaccio's knowledge in this area as well as his ability to use animals in a way that is similar to how his predecessors had used them. ${ }^{40}$

In the Decameron, the animal characters prove to be more complex, and their purpose, multifaceted. A primary feature of the wolves and dogs in these tales is their movement away from a purely symbolic role to a more active one, one in which they function as agents of change within the stories themselves. They are used to represent and serve the goals of their respective novelle, of the storytellers, and, especially, of the underlying messages of those tales. The beasts of the Decameron are more lifelike than their predecessors, even as they continue to operate on a symbolic level; but Boccaccio's beasts are symbolic in a new, transformative way. They now serve as "exemplars" of a morality based on an ironic examination of human nature, heralding the Renaissance's shift away from the intense medieval focus on spiritual guidance. For medieval philosophers, the ultimate goal in studying animals was not to learn about animals but "to better understand human nature" (De Leemans and Klemm 153). What animals say about the texts they inhabit is just as relevant. The Decameron presented a new way of interpreting the human experience to the world, and this is reflected in the portrayal of its canids, even as they continue to share many qualities with their medieval antecedents. In Boccaccio's text, as in the work of his predecessor Dante, the treatment of dogs and wolves tells us not only about the nature of the characters featured, but also, and more critically, about the characteristics the authors wished to assume for their narrators, for themselves, and for the messages they conveyed to their readers.

\footnotetext{
${ }^{39}$ Victoria Kirkham reads the allegory not only as the defeat of vice by virtue but also as one "of conversion from bestial lust to Christian love" (304).

${ }^{40}$ For discussion on the numerous sources for this work, including the influence of the bestiaries, see the introduction to Diana's Hunt (Cassell and Kirkham 1-96).
} 


\section{Works Cited}

Albertus Magnus. On Animals: A Medieval "Summa Zoologica." 2 vols. Trans. Kenneth F. Kitchell Jr. and Irven Michael Resnick. Baltimore: Johns Hopkins UP, 1999.

Alighieri, Dante. The Divine Comedy. 3 vols. Ed. and trans. Charles S. Singleton. Princeton: Princeton UP, 1989. . "Sonar bracchetti." In Rime. Ed. Domenico De Robertis. Florence: Sismel, 2005. 314-317.

Badke, David. The Medieval Bestiary. 12 Jan. 2011. http://bestiary.ca/ 14 Apr. 2013.

Baldi, Andrea. "La retorica dell'"exemplum' nella novella di Nastagio." Italian Quarterly 32 (1995): 17-28.

Boccaccio, Giovanni. Boccaccio's Expositions on Dante's "Comedy." Ed. and trans. Michael Papio. Toronto: U of Toronto P, 2009.

. "Caccia di Diana.” In Tutte le opere. Vol. 1. Ed. Vittore Branca. Verona: Mondadori, 1967.

. "Carmina." In Tutte le opere di Giovanni Boccaccio. Vol. 5. Ed. Vittore Branca. Milan: Mondadori, 1992.

. Decameron. 2 vols. Ed. Vittore Branca. Turin: Einaudi, 1992.

. The Decameron. Trans. Mark Musa and Peter Bondanella. New York:

Mentor, 1982.

. Eclogues. Trans. Janet Levarie Smarr. New York: Garland, 1987.

. Esposizioni sopra la Comedia di Dante. Ed. Giorgio Padoan. Verona: Mondadori, 1965.

. The Life of Dante (Trattatello in laude di Dante). Trans. Vincenzo Zin Bollettino. New York: Garland, 1990.

. "Trattatello in laude di Dante." In Tutte le Opere di Giovanni Boccaccio.

Vol. 3. Ed. Vittore Branca. Verona: Mondadori, 1974. 425-496.

Boethius. The Consolation of Philosophy. Trans. W. V. Cooper. New York: Random House, 1943.

Cassell, Anthony K., and Victoria Kirkham, eds. and trans. Diana's Hunt_Caccia di Diana: Boccaccio’s First Fiction. By Giovanni Boccaccio. Philadelphia: U of Pennsylvania P, 1991.

Cozzarelli, Julia. "Canines in the Classroom: Boccaccio, Dante, and the Visual Arts." Humanities 5.3 (2016). Article 68. 
De Leemans, Peter, and Matthew Klemm. "Animals and Anthropology in Medieval Philosophy." In A Cultural History of Animals in the Medieval Age. Ed. Brigitte Resl. Oxford: Berg, 2011: 153-178.

Fleming, Ray. "Happy Endings? Resisting Women and the Economy of Love in Day Five of Boccaccio's Decameron." Italica 70.1 (Spring 1993): 30-45.

Garver, M.S., and K. McKenzie, eds. Il bestiario toscano secondo la lezione dei codici di Parigi e di Roma. Rome: Società Filologica Romana, 1912.

Giusti, Eugenio L. Dall'amore cortese alla comprensione: Il viaggio ideologico di Giovanni Boccaccio dalla "Caccia di Diana" al "Decameron." Milan: LED, 1999.

Hollander, Robert. Boccaccio's Dante and the Shaping Force of Satire. Ann Arbor: U of Michigan P, 1997.

Houston, Jason M. Building a Monument to Dante: Boccaccio as "Dantista." Toronto: $\mathrm{U}$ of Toronto P, 2010.

Kalof, Linda, and Brigitte Resl, eds. A Cultural History of Animals. 6 vols. Oxford: Berg, 2011.

Kirkham, Victoria. "Numerology and Allegory in Boccaccio's Caccia di Diana." Traditio 34 (1978): 303-329.

Kleinhenz, Christopher. "Infernal Guardians Revisited: 'Cerbero, il gran vermo' (Inf. VI, 22).” Dante Studies 93 (1975): 185-199.

. "Notes on Dante's Use of Classical Myths and the Mythographical Tradition.” Romance Quarterly 33 (1986): 477-484.

Livanos, Christopher. "Dante's Monsters: Nature and Evil in the Commedia." Dante Studies 127 (2009): 81-92.

Manguel, Alberto. “Dante's Dog." PN Review 192 (2010): 14-18.

Marchesi, Simone. "Dire la verità dei sogni: la teoria di Panfilo in Decameron IV.6." Italica 81.2 (2004): 170-183.

. "Intenzionalità tragica e intendimento comico in Decameron, V 8." Humanistica 4.2 (2009): 31-41.

Mazzoni, Cristina. She-Wolf: The Story of a Roman Icon. New York: Cambridge UP, 2010.

Ó Cuilleanáin, Cormac. "Man and Beast in the Decameron." Modern Language Review 75.1 (1980): 86-93.

Passavanti, Iacopo. Lo specchio della vera penitenza. $2^{\text {nd }}$ ed. Ed. F. L. Polidori. Florence: Felice le Monnier, 1863. Internet Archive. 29 May 2016. 
Resl, Brigitte. "Animals in Culture, ca. 1000-ca. 1400." In A Cultural History of Animals in the Medieval Age. Ed. Brigitte Resl. Oxford: Berg, 2011. 1-26.

Rowland, Beryl. Animals with Human Faces: A Guide to Animal Symbolism. Knoxville: $U$ of Tennessee P, 1973.

Salisbury, Joyce E. The Beast Within: Animals in the Middle Ages. 2nd ed. New York: Routledge, 2011.

Scordilis Brownlee, Marina. "Wolves and Sheep: Symmetrical Undermining in Day III of the Decameron." Romance Notes 24.3 (1984): 262-266.

Singleton, Charles S. The Divine Comedy: Inferno. Vol. 2: Commentary. Princeton: Princeton UP, 1989.

Sinicropi, Giovanni. "La cagna la mula la menade, e Nastagio degli Onesti." Comunità XLII.189/190 (1988): 380-429.

Smets, An, and Baudouin van den Abeele. "Medieval Hunting." In A Cultural History of Animals in the Medieval Age. Ed. Brigitte Resl. Oxford: Berg, 2011. 59-80. 
